\title{
Rekrutmen Elit Birokrasi, Desentralisasi Salah Kaprah? Sebuah Studi Terhadap Penataan Jabatan Struktural di Kabupaten Gorontalo Utara
}

\author{
Nur Istiyan Harun \\ Program Studi Ilmu Pemerintahan \\ Universitas Gorontalo \\ isty.harunc@gmail.com
}

\begin{abstract}
This study discusses how the recruitment process of the bureaucratic elite that occurred in North Gorontalo Regency and what factors influenced the recruitment process. This study uses a case study method to assist researchers in retrieving data. Because the specifics of this study want to explain how the structural structuring process is in North Gorontalo Regency. With this method researchers can familiarize themselves with research subjects directly to a certain time by applying data collection techniques through observation, documentary and in-depth interviews.

The results of the study show that the recruitment process of bureaucratic elites in North Gorontalo Regency is not in accordance with Government Regulation of the Republic of Indonesia number 13 of 2002 concerning changes to Republic of Indonesia Government Regulation number 100 of 2000 concerning the appointment of civil servants in structural agreements. This happened because the North Gorontalo District including the newly created area was established in 20017 which affected the human resources (HR), work facilities, and work programs of the Regional Government.
\end{abstract}

Keywords: elite recruitment of bureaucracy; decentralization; structural position arrangement.

\section{ABSTRAK}

Penelitian ini bertujuan untuk menggambarkan bagaimana proses rekrutmen elit birokrasi yang terjadi di Kabupaten Gorontalo Utara dan faktor apa saja yang mempengaruhi proses rekrutmen tersebut. Penelitian ini menggunakan metode studi kasus sebagai langkah untuk membantu peneliti dalam pengambilan data. Karena spesifik penelitian ini ingin menjelaskan bagaimana proses penataan jabatan struktural yang ada di Kabupaten Gorontalo Utara. Dengan metode ini peneliti dapat mengakrabkan diri dengan subyek penelitian secara langsung dalam waktu tertentu dengan menerapkan teknik pengumpulan data melalui observasi, dokumenter dan wawancara mendalam.

Dari hasil penelitian menunjukan bahwa proses rekrutmen elit birokrasi di Kabupaten Gorontalo Utara tidak sepenuhnya sesuai dengan Peraturan Pemerintah Republik Indonesia nomor 13 tahun 2002 tentang perubahan atas Peraturan Pemerintah Republik Indonesia nomor 100 tahun 2000 tentang pengangkatan pegawai negeri sipil dalam jabatan struktural. Hal itu terjadi karena Kabupaten Gorontalo Utara termasuk daerah pemekaran yang baru di mekarkan pada tahun 20017 sehingga berdampak pada keterbatasan sumber daya manusia (SDM), kondisi fasilitas kerja, dan program kerja Pemerintah Daerah.

Kata Kunci : rekrutmen elit birokrasi; desentralisasi; penataan jabatan struktural. 


\section{PENDAHULUAN}

Dalam penyelenggaraan pemerintahan di Indonesia, daerah diberikan kesempatan dan keleluasaan untuk menyelenggarakan otonomi daerah seluasluasnya sebagaimana dimaksud pada Pasal 18 ayat (5) UUD 1945. Melalui pelimpahan wewenang itulah para birokrat pada tingkat bawah diberi kesempatan untuk mengambil inisiatif dan mengembangkan kreativitas mereka, mencari solusi terbaik atas setiap masalah yang dihadapi dalam pelaksanaan tugas sehari-hari. Penyelenggaraan otonomi daerah dilaksanakan dengan memberikan kewenangan yang luas, nyata dan bertanggung jawab kepada daerah secara proporsional yang diwujudkan dengan pengaturan, pembagian dan pemanfaatan sumber daya nasional yang berkeadilan serta perimbangan keuangan pusat dan daerah.

Keberhasilan pelaksanaan otonomi daerah juga sangat tergantung pada manusia pelaksana harus baik, keuangan harus cukup baik, peralatannya harus cukup dan baik serta organisasi dan manajemennya harus baik. Dari berbagai faktor tersebut, faktor manusia atau sumber daya aparatur yang menjadi faktor utama dan esensial, karena manusia di samping menjadi objek juga sebagai subjek dalam segala aktivitas pemerintahan.

Terdapat beberapa determinan yang mendorong sumber daya aparatur harus segera berbenah diri antara lain reformasi birokrasi dengan tuntutan untuk memperbaiki kinerja pemerintah menuju birokrasi yang bersih dan melayani. Reformasi birokrasi pada hakikatnya adalah suatu proses transformasi mindset dan culture-set yang terarah pada tatanan birokrasi yang efektif dan efisien yang dijiwai dengan semangat terwujudnya pemerintahan yang amanah atau tata kepemerintahan yang baik (good governance) sehingga dapat memberikan pelayanan yang lebih optimal kepada masyarakat.

Oleh sebab itu masalah utama dalam pelaksanaan otonomi daerah yaitu pada masalah peningkatan kualitas sumber daya manusia dan aparaturnya. Kita memerlukan sumber daya manusia yang berkualitas dan profesional di bidangnya masing-masing. Sumber daya manusia yang memiliki kualifikasi berupa spesialisasi dalam bidang-bidang yang telah dikuasai dan ditekuninya. Sehingga bisa lahir aparatur yang mampu mencari terobosan baru ke arah yang lebih baik, mampu berfikir yang inovatif, kreatif, mampu menciptakan suasana kerja yang kondusif sehingga mampu menghasilkan kinerja yang efektif, efisien dalam proses pembangunan maupun dalam pemberian pelayanan kepada masyarakat.

Untuk mewujudkan penyelenggaraan pemerintahan dan pembangunan yang demikian, diperlukan Pegawai Negeri Sipil yang profesional, bertanggung jawab, jujur dan adil melalui pembinaan yang dilaksanakan berdasarkan prestasi kerja dan sistem karir yang dititikberatkan pada sistem prestasi kerja.

Berdasarkan Undang-Undang Nomor 32 tahun 2004 tentang Pemerintahan Daerah, Kepala Daerah memiliki peranan dalam melaksanakan manajemen kepegawaian daerah meliputi penetapan formasi, pengadaan, pengangkatan, pemindahan, pemberhentian, penetapan pensiun, gaji, tunjangan, kesejahteraan, hak dan kewajiban, kedudukan hukum, pengembangan potensi dan pengendalian jumlah.

Pelaksanaan sebagian kewenangan di atas, dalam kenyataannya banyak permasalahan yang cukup krusial. Sebagai gambaran penataan jabatan struktural di lingkungan pemerintahan Kabupaten Gorontalo Utara. Terbukti 
dari sebelas (11) Kecamatan di Kabupaten Gorontalo Utara, lima (5) di antaranya diketahui Camat yang bergelar Sarjana Pendidikan (S.Pd), gelar selain Sarjana Pemerintahan ada lima (5) orang. Pemimpin SKPD selain dinas Pendidikan, yang memiliki gelar Sarjana Pendidikan (S.Pd) ada empat (4) orang. Masalah yang demikian, erat kaitannya dengan kedudukan dan kewenangan para pejabat pemerintah yang hingga kini senantiasa disorot oleh berbagai kalangan. Kondisi ini menggiring opini publik bahwa kebijakan pengangkatan dalam jabatan struktural dan mutasi pegawai di daerah Gorontalo Utara yang masih banyak diwarnai faktor politik dan berbagai kepentingan baik kepentingan elit politik maupun elit eksekutif.

Oleh karena itu penelitian ini menjadi penting, untuk dapat mengkaji lebih dalam bagaimana proses rekrutmen elit birokrasi di Kabupaten Gorontalo Utara. Berdasarkan uraian pada latar belakang diatas, maka fokus masalah yang dikaji dalam penelitian ini, adalah megenai proses rekruitmen pejabat struktural di Kabupaten Gorontalo Utara.

Rekrutmen merupakan proses untuk mengisi posisi jabatan tertentu. Rekrutmen merupakan terminologi lebih luas perumpamaan sebagai upaya untuk mendapatkan SDM dalam suatu organisasi. Dalam perencanaan SDM, rekrutmen dan seleksi merupakan tahapan dalam rangka pengadaan. Pengadaan SDM didasarkan analisis kebutuhan SDM setiap organisasi/unit organisasi. Wujud analisis kebutuhan SDM dapat baru analisis jabatan dan atau formasi kebutuhan pegawai. Analisis kebutuhan SDM merupakan kegiatan untuk menentukan berapa jumlah dan kualifikasi kebutuhan SDM setiap satuan organisasi. Analisis kebutuhan pegawai didasarkan pada volume/beban ketugasan setiap jabatan. Setiap jabatan ditentukan kualifikasi persyaratan: baik didasarkan pada kualifikasi pendidikan, kepangkatan, pengalaman,maupun kompotensi jabatan.

Adapun prosedur pemilihan SDM yang akan direkrut dalam jabatan struktural sebagaimana aturan yang dituangkan dalam peraturan pemerintah Republik Indonesia nomor 13 tahun 2002 tentang pengangkatan pegawai negeri sipil dalam jabatan struktural pada pasal 5 dan 6, dengan perlu memperhatikan faktor senioritas dalam kepangkatan, usia, pendidikan dan pelatihan jabatan dan pengalaman yang dimiliki.

Selama ini, birokrasi dikalangan masyarakat dipahami sebagai sebuah tahapan didalam organisasi yang melayani masyarakat dengan stereotipe negatif. Misalkan, prosedur yang berbelit-belit, tidak adil, tidak ramah, memerlukan waktu yang lama dan ujung-ujungnya adalah biaya yang serba mahal. Anggapan seperti ini tidak dapat disalahkan karena masyarakat menggambarkan birokrasi dengan hal-hal demikian sesuai dengan pengalaman yang masyarakat alami pada saat pengurusan KTP, kartu keluarga, akta kelahiran dan lain-lain.

Konsep birokrasi dimunculkan oleh M. De Gourney. Melalui surat tertanggal 1Juli 1764 yang di tulis Baran de Grim, merujuk pada gagasan Gouney yang mengeluhkan tentang pemerintahan yang melayani dirinya sendiri. De Gourney menyebutkan kecendrungan itu sebagai penyakit yang disebutnya bureaumania. Birokrasi yang dalam bahasa Inggris, bureaucracy, berasal dari kata bureau (berarti: meja) dan cratein (berarti: kekuasaan), dimaksudkan adalah kekuasaan berada pada orang-orang yang dibelakang meja. 
Agar tujuan organisasi dapat tercapai sesuai dengan yang di rencanaan maka prinsip dasar dan karakteristik ideal birokrasi perlu dimiliki oleh para birokrat (pegawai negeri sipil). Selain karakteristik ideal birokrasi, para birokrat perlu memperhatikan tipe ideal struktur birokrasi agar tugas-tugas administrasi yang besar dapat dilaksanakan secara efektif dan efisien. Sehingga pendapat sebagian masyarakat selama ini yang cendrung negatif paling tidak dapat diluruskan. Dengan mengutip pendapat Max Weber seorang sosiolog Jerman, (Tjokroamidjojo dalam Anggara (2013:251-255) mengemukakan tipe ideal struktur birokrasi, yaitu sebagai berikut:1) Prinsip pembagian kerja, 2) Struktur hierarkis, 3) Aturan dan prosedur, 4) Prinsip netral (tidak memihak), 5) Penempatan didasarkan atas karier dan, 6) Birokrasi murni.

Prasojo dalam Purnandini, (2017), mengeukakan bahwa terkait dengan persoalan rekrutmen, dapat disebutkan beberapa situasi problematik yang dihadapi oleh birokrasi di Indonesia. Proses rekrutmen masih belum dilakukan secara profesional dan masih terkait dengan hubungan - hubungan kolusi, korupsi dan nepotisme. Rekrutmen pegawai masih dipandang seakan - akan mejadi kebutuhan proyek tahunan dan bukan sebagai kebutuhan akan peningkatan kualitas pelayanan publik dan penyelenggaraan pemerintahan. Indikasi ini sangat nyata apabila dilihat bahwa job analylis sebagai per-syaratan untuk menentukan job requitment masih belum dimiliki oleh pemerintah.

Konsep desentralisasi yang memanifestasikan konsep otonomi daerah yang berimplikasi terhadap upaya penguatan penyelenggaraan pemerintahan daerah yang berbasis pada potensi lokal dan kewenangan oleh Pemerintah Daerah untuk menentukan elit birokrasi telah menyebabkan rekrutmen dilakukan secara serampangan dan tidak memperhatikan kualifikasi yang dibutuhkan. Hal demikian terhadap manajemen sumber daya aparatur dalam hal ini proses rekrutmen elit birokrasi yang nantinya akan menduduki jabatan struktural, sangat rentan dan potensial terhadap praktek spoil system. Salah satu upaya yang harus dilakukan untuk meminimalisir segala bentuk penyimpangan dalam rangka proses rekrutmen adalah dengan cara menerapkan merit system, sebagai antitesis dari penataan jabatan struktural atas dasar senioritas dalam kepangkatan, usia, pendidikan dan pelatihan jabatan dan pengalaman yang dimiliki sebagaimana yang tertulis dalam Peraturan Pemerintah Republik Indonesia nomor 13 tahun 2002 tentang perubahan atas Peraturan Pemerintah Republik Indonesia nomor 100 tahun 2000 tentang pengangkatan pegawai negeri sipil dalam jabatan struktural. Dalam hal ini, peneliti bermaksud menggambarkan sejauh mana Pemerintah Daerah Gorontalo Utara menerapkan aturan tersebut dalam proses rekrutmen pejabat struktural.

\section{METODE PENELITIAN}

Penelitian ini menggunakan pendekatan penelitian kualitatif dan sumber data yang digunakan meliputi data primer dan sekunder. Data primer di peroleh dari pejabat-pejabat terkait di lingkungan Pemerintah Daerah Gorontalo Utara. Sedangkan data sekunder diperoleh dari dokumen berupa laporan.

Adapun teknik pengumpulan data dilakukan melalui tiga tehnik. 1). Dengan teknik wawancara, bisa diharapkan akan diperoleh informasi dan data mengenai proses rekrutmen pejabat struktural serta kendala yang dihadapi, oleh karena itu unit analisis dari penelitian ini adalah individu. 2) Observasi 
digunakan dalam pengambilan data dengan pengamatan dan pencatatan sistematis di lapangan untuk memperoleh data yang diperlukan tetapi tidak diperoleh dalam wawancara. Dan yang ke-3) dokumenter, di mana peneliti dalam pengambilan data dengan mempelajari berbagai dokumen yang terkait.

\section{HASIL PENELITIAN DAN PEMBAHASAN \\ 3.1. Rekrutmen Elit Birokrasi}

Kegiatan penataan kelembagaan dalam bentuk perubahan atau perombakan Struktur Organisasi dan Tata Kerja lembaga perangkat Daerah senantiasa mendatangkan reaksi yang beragam di kalangan birokrasi yang ada. Banyak yang menanggapi positif, tetapi tidak sedikit pula yang menangapi secara negatif. Padahal kegiatan penataan kelembagaan sama sekali tidak pernah dimaksudkan untuk menggusur kemapanan yang telah ada, tetapi dimaksudkan untuk lebih meningkatkan kinerja lembaga perangkat daerah yang ada.

Penataan kelembagaan perangkat daerah harusnya tidak dilakukan secara asal - asalan tetapi didasarkan pada ketentuan perundang-undangan yang ditetapkan oleh Pemerintah Pusat. Sebelum dilakukan penataan, juga telah dilakukan telaah dan kajian yang mendalam dari segi kewenangan, kebutuhan dan kemampuan daerah untuk memberikan pembiayaan akibat dari penataan kelembagaan tersebut. Walaupun tidak terbit peraturan baru yang mengatur tentang kelembagaan perangkat daerah, pada waktu-waktu tertentu juga diadakan evaluasi kelembagaan, sebagai bahan untuk penataan atau pembenahan organisasi, karena pada hakekatnya organisasi pemerintah daerah selalu berubah sesuai dengan tuntutan dan kebutuhan daerah.

Rekrutmen merupakan fungsi manajemen sumberdaya manusia yang sangat menarik dan penting sekali karena dalam prakteknya berkaitan dengan nilai-nilai dan kondisi-kondisi lingkungan sekitar baik dari aspek sosial, ekonomi maupun politik. Menurut Klinger seperti yang disebut Faustino Cardoso Gomes, menyebutkan bahwa, rekruitmen itu dipengaruhi oleh tiga nilai utama yang saling berbeda dan bahkan saling berlawanan, yang meliputi:

(1) Keadilan Sosial, termasuk affirmative action (2) Efisiensi manajemen dan (3) Daya tanggap politik.

Dari uraian tersebut dapat diartikan bahwa rekrutmen diperlukan karena adanya faktor kebutuhan akan penempatan personal sesuai dengan keahlian yang dimilikinya (the right man on the right place), serta faktor kebutuhan organisasi dalam upaya mendukung kegiatan efisiensi dan efektivitas tujuan organisasi, serta untuk kepentingan memelihara kendali terhadap kaum birokrat yang terpilih menjadi pejabat.

Dari hasil penelitian terkait dengan rekrutmen elit birokrasi atau pejabat struktural di Kabupaten Gorontalo Utara diketahui masih belum sepenuhnya sesuai sebagaimana pada yang di syaratkan dalam PP nomor 13 tahun 2002. Hal ini diketahui dari hasil wawancara peneliti dengan sekertaris BKD Kabupaten Gorontalo Utara, beliau mengatakan :

"Kami selaku Pemerintah Daerah Kabupaten Gorontalo Utara sudah melakukan perekrutan sesuai dengan prosedur. Memang syarat yang terdapat pada PP nomor 13 tahun 2002 tidak sepenuhnya kami lakukan karena mengingat sumber daya yang ada di lingkungan Kabupaten Gorontalo Utara masih kurang 
dan kami tidak mungkin membiarkan jabatan-jabatan struktural tersebut kosong."

Pernyataan senada juga di sampaikan oleh Sekertaris Daerah Kabupaten Gorontalo Utara :

"Tidak ada yang di namakan desentralisasi salah kaprah dalam Pemerintahan Kabupaten Gorontalo Utara. Kenapa banyak pejabat struktural yang menduduki posisi penting namun tidak sesuai dengan keilmuan yang di miliki itu karena Gorontalo Utara minim sumber daya aparaturnya, hal ini terjadi karena Gorontalo Utara baru di mekarkan pada tahun 2007. Sehingga kami harus menempatkan sarjana-sarjana Pendidikan itu menjadi camat dan kepala SKPD. Terkait dengan perekrutan calon pegawai negeri sipil yang keilmuannya kurang di Gorontalo Utara, kami sudah mengusulkan untuk merekrutnya. Tapi perlu untuk di ketahui bahwa usulan yang kami ajukan juga tidak sepenuhnya di terima”.

Berdasarkan uraian di atas proses rekrutmen elit birokrasi di Kabupaten Gorontalo Utara, Pemerintah daerah mengalami masalah pada sumber daya aparatur. Hal ini kemudian yang berdampak pada penataan jabatan struktural yang ada di Kabupaten Gorontalo Utara. Masalah ini disebabkan karena Gorontalo Utara merupakan daerah yang baru dimekarkan dari Kabupaten Gorontalo pada tahun 2007.

Bupati Kabupaten Gorontalo Utara sebagai kepala daerah memiliki kewenangan otoritas melakukan suatu pengambilan kebijakan, diantaranya untuk memenuhi kebutuhan daerah. Penilaian dan pertimbangan rekrutmen dilakukan oleh Baperjakat dengan memperhatikan beberapa syarat yang tertuang dalam PP nomor 13 tahun 2002 tentang pengangkatan pegawai negeri sipil dalam jabatan struktural, yakni PNS, kepangkatan, kualifikasi/pendidikan, prestasi kerja, kompetensi jabatan dan kesehatan. Akan tetapi, bupati memiliki kewenangan untuk memutuskan siapa yang di anggap berkompeten untuk menduduki formasi jabatan yang kosong.

Penataan jabatan struktural di Kabupaten Gorontalo Utara kurang memperhatikan tipe ideal dari elit birokrasi sebagaimana prasyarat yang tercantum dalam PP nomor 13 tahun 2002, dimana perekrutan hanya didasarkan pada unsur kepangkatan dan mengabaikan unsur lainnya. Dari hasil penelitian, peneliti menemukan bahwa ada nuansa politis yang menjadi salah satu faktor dari pada rekrutmen elit birokrasi di Kabupatan Gorontalo Utara. Namun, nuansa politis ini bukan berarti terjadi desentraslisasi salah kaprah yang dilakukan oleh Bupati Kabupaten Gorontalo Utara.

\subsection{Faktor Yang Mempengaruhi Proses Rekrutmen}

Berdasarkan hasil penelitian, peneliti mendapatkan 2 (dua) kendala utama didalam pelaksanaan rekruitmen pejabat struktural di Kabupaten Gorontalo Utara yaitu :

\section{Sumber Daya Manusia (SDM)}

Keberhasilan pelaksanaan otonomi daerah juga sangat tergantung pada manusia pelaksana harus baik, keuangan harus cukup baik, peralatannya harus cukup dan baik serta organisasi dan manajemennya harus baik. Dari berbagai 
faktor tersebut, faktor manusia atau sumber daya aparatur yang menjadi faktor utama dan esensial, karena manusia di samping menjadi objek juga sebagai subjek dalam segala aktivitas pemerintahan.

Dalam proses rekrutmen elit birokrasi di Kabupaten Gorontalo Utara, sumber daya manusia menjadi faktor utama dalam proses rekrutmen. Tidak terpenuhinya seluruh prosedur yang ada pada PP nomor 13 tahun 2002 di akibatkan oleh kurangnya aparatur sipil negara di Kabupaten Gorontalo Utara. Hal ini terjadi karena Kabupaten Gorontalo Utara merupakan daerah mekaran, yang baru di mekarkan dari Kabupaten Gorontalo pada tahun 2007.

\section{Sinkronisasi Pusat - Daerah}

Dalam hal ini adalah sering tidak diterimanya usulan oleh Pemerintah Daerah Kabupaten Gorontalo Utara dalam merekrut calon pegawai negeri sipil dari beberapa basis keilmuan oleh Pemerintah Pusat. Sebagaimana hasil wawancara oleh peneliti dengan sekertaris daerah Kabupaten Gorontalo Utara, di ketahui bahwa pengusulan beberapa formasi dan kuota calon pegawai Pemerintah Daerah Gorontalo Utara seringkali di setujui tidak sesuai dengan pengusulan. Hal ini menjadikan kompetensi dan keterampilan tidak menjadi pertimbangan utama di dalam proses perekrutan.

\section{Penutup}

Seiring dengan tuntutan dan tantangan pelaksanaan otonomi daerah maka pemerintah daerah dituntut untuk dapat menggali potensi daerah dan mengelola potensi sumber daya aparatur untuk mencapai efektifitas dan efisiensi dalam penyelenggaraan tugas pemerintahan. Upaya peningkatan kualitas profesionalisme Pegawai Negeri Sipil yang memiliki keunggulan kompetitif dan memegang teguh etika birokrasi dalam memberikan pelayanan yang sesuai dengan tingkat kepuasan dan keinginan masyarakat adalah suatu kebutuhan mutlak bagi pemerintah daerah.

Penataan jabatan struktural adalah kewenangan Kepala Daerah, setelah melalui pertimbangan Baperjakat. Intervensi politis dalam penataan jabatan struktural adalah sebuah keniscayaan, namun, syarat yang tertuang dalam PP nomor 13 tahun 2002 tentang pengangkatan pegawai negeri sipil dalam jabatan struktural harus menjadi acuan. Kepentingan politik tidak seharusnya menghilangkan prinsip merit system. Antara politik dan administrasi ada pemisahan yang jelas yang harus diperhatikan oleh Kepala Daerah.

Berdasarkan hasil penelitian, peneliti mendapatkan 2 (dua) kendala utama didalam pelaksanaan rekruitmen pejabat struktural di Kabupaten Gorntalog Utara yaitu, sumber daya manusia (SDM) dan sering tidak di terimanya usulan oleh Pemerintah Daerah Kabupaten Gorontalo Utara dalam merekrut calon pegawai negeri sipil dari beberapa basic keilmuan oleh Pemerintah Pusat.

\section{REFERENSI}

Anggara, Sahya. 2013. Sistem Politik Indonesia, Bandung: CV Pustaka Setia

Mashuri, 2007. Penetrasi Politik Dalam Rekrutmen Elit Birokrasi

Timmer, Jaap. 2007. Dalam Politik Lokal di Indonesia, Desentralisasi Salah Kaprah dan Politik Elit di Papua, Jakarta:KITLV-Jakarta. 
Farasita Anggit Purnandini Rekrutmen Elit Birokrasi Di Lingkungan Sekretariat Daerah Provinsi Jawa Tengah Tahun 2013-2015 di http://www.fisip.undip.ac.id/ di akses pada 17 April 2019.

Mahathir Muhammad Iqbal, 2017. Membangun Sistem Rekrutmen Calon Pegawai Negeri Sipil Pada Era Otonomi Daerah di

http://journal.umpo.ac.id/index.php/aristo / aristo@umpo.ac.id. di akses pada 17 April 2019.

Wawancara dengan Sekertaris Daerah Gorontalo Utara

Wawancara dengan Asisten 1 Gorontalo Utara

Wawancara dengan Kepala Pemerintahan Gorontalo Utara

Wawancara dengan Kepala SKPD di Lingkungan Gorontalo Utara 